\title{
Gadget Addiction Factors in Malaysia: A Literature Review
}

Abdullah Abdol Razak, Wan Mohd Khairul Firdaus Wan Khairuldin, Hannan Fatini Md. Reshad, Mohamad Zaidin bin Mat@Mohamad, Wan Nur Izzati Wan Nor Anas

To Link this Article: http://dx.doi.org/10.6007/IJARBSS/v11-i2/8650

DOI:10.6007/IJARBSS/v11-i2/8650

Received: 15 December 2020, Revised: 09 January 2021, Accepted: 25 January 2021

Published Online: 11 February 2021

In-Text Citation: (Abdol Razak et al., 2021)

To Cite this Article: Abdol Razak, A., Khairuldin, W. M. K. F. W., Reshad, H. F. M., Mohamad, M. Z. B. M@., \& Anas, W. N. I. W. N. (2021). Gadget Addiction Factors in Malaysia: A Literature Review. International Journal of Academic Research in Business and Social Sciences, 11(2), 151-156.

\section{Copyright: @ 2021 The Author(s)}

Published by Human Resource Management Academic Research Society (www.hrmars.com)

This article is published under the Creative Commons Attribution (CC BY 4.0) license. Anyone may reproduce, distribute, translate and create derivative works of this article (for both commercial and non-commercial purposes), subject to full attribution to the original publication and authors. The full terms of this license may be seen at: http://creativecommons.org/licences/by/4.0/legalcode

Vol. 11, No. 2, 2021, Pg. 151 - 156

Full Terms \& Conditions of access and use can be found at http://hrmars.com/index.php/pages/detail/publication-ethics 


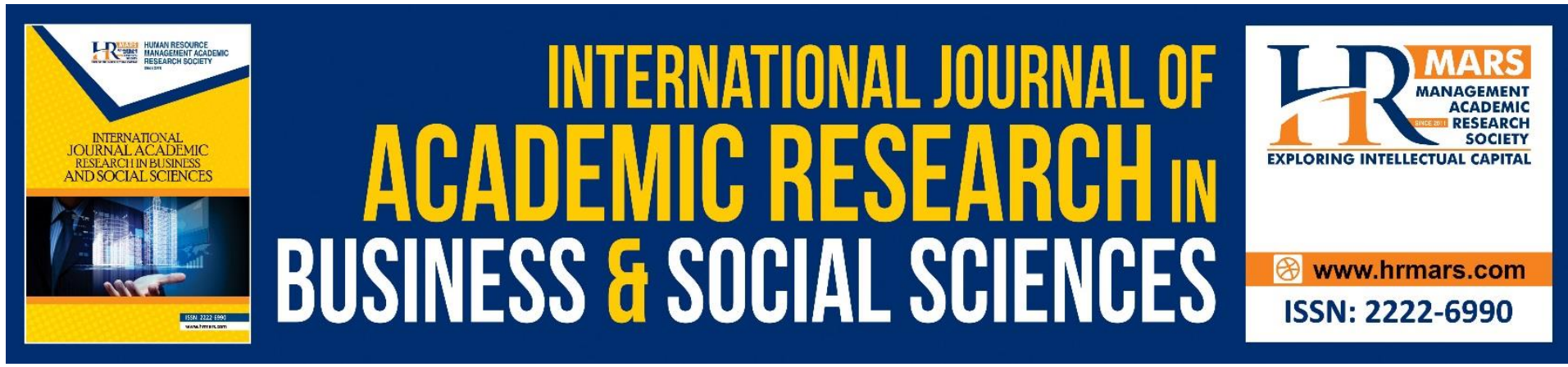

\title{
Gadget Addiction Factors in Malaysia: A Literature Review
}

\author{
Abdullah Abdol Razak ${ }^{1}$, Wan Mohd Khairul Firdaus Wan \\ Khairuldin ${ }^{1}$, Hannan Fatini Md. Reshad ${ }^{1}$, Mohamad Zaidin bin \\ Mat@Mohamad', Wan Nur Izzati Wan Nor Anas² \\ ${ }^{1}$ Faculty of Islamic Contemporary Studies, Universiti Sultan Zainal Abidin, ${ }^{2}$ Academy of \\ Islamic Studies, University of Malaya \\ Email:wanfirdaus@unisza.edu.my
}

\begin{abstract}
Gadget addiction is a phenomenon that has a negative impact nowadays. While gadgets have their own benefits in helping consumers in a variety of daily lives, overuse can lead to side problems. In Malaysia, the use of gadgets in daily life is very high. There are various factors that lead to gadget addiction in Malaysia. This study aims to examine the factor of gadget addiction that occurs in Malaysia. There are several factors that contribute to gadget addiction. Among those factors is excessive use to exceed the proper time. In addition, no supervision from parents also contributes to the addiction of this gadget. Furthemore, gadget addiction in Malaysia not only involves phones and tablets, but also includes various forms of gadgets.
\end{abstract}

Keywords: Addiction, Gadgets, Literature, Factors.

\section{Introduction}

The development of globalization in society today has a lot of impact on progress and facilities, especially in terms of information and communication technology. The use of cyber in various scopes provides benefits including the provision of information, ideas, views, entertainment and so on easily and quickly (Sakai, Malek \& Sombuling, 2017). World Internet Statistics (Internet World Stats) revealed almost 78.8\% of internet users in the country, especially children are seriously addicted. This addiction is a worrying situation when children aged two to three are mostly allowed to play electronic gadgets such as i-Pad and mobile phones as a substitute for parents or caregivers (Hamid, 2017). Based on the Cyber Security Awareness Benchmark Survey conducted by CyberSecurity and the Ministry of Education in 2016,45 percent of children aged seven to nine years in the country are already proficient in using the internet. While almost $92.5 \%$ of children and adolescents between the ages of 13 to 17 today, are hardcore internet users.

Al Mazmi, Aslam and Rajan (2013) formulate some negative effects of the use of gadgets including limiting external movements and activities, promoting self-satisfaction that leads to 
addiction, and lack of social skills including inability to understand body language. More worryingly, the use of these gadgets will also cause violent behavior, stress, depression and confusion. Excessive use of touch screen can also result in children experiencing long-term health effects (Marzoli, 2013).

Various terms were given by previous researchers namely compulsive internet use, pathological internet use, internet usage disorder, and problematic internet use to describe the phenomenon of individuals engaging in excessive and unhealthy internet use (Ghina \& Griffiths, 2006; Yao \& Zhong, 2014). Internet use has been defined as a problem of behavior control and the inability of internet users to control its use in moderation which in turn causes frustration and deterioration of function in daily life (Shek, Sun \& Yu, 2013; Yao \& Zhong, 2014).

Although there are various problems mentioned from previous studies, addiction to the cyber world, one of which is addiction to gadgets, has not yet had a significant recovery effect. Therefore, religious solutions need to find a place as one of the alternatives to this addictive solution. According to Jasimah, Radzi and Bakar (1996), Islam is a religion that does not deny human involvement in technological progress. In fact, Islam emphasizes to integrate the development of technology as well as other sciences with the concept of 'ubudiyyah (devotion to Allah). The integration in balancing the will of man with his environment (Rahman, 1998) that is in the present case is the interaction with the cyber world. Islam also recognizes the advancement of technology by laying down specific ethics so that people can evaluate the pros and cons of something in their daily lives (Zain, 2002).

\section{Literature on the Impact of Cyber Addiction}

The use of mobile devices in the cyber world provides great benefits, but at the same time brings the extreme addiction to become an epidemic that needs to be restored. According to Suler (1999), excessive and uncontrolled use of mobile devices contributes to problems to its users whether in relationships, careers, and psychological well-being. The higher the usage, the higher the users become addicted to the cyber world. Social site sharing which is a phenomenon today is one of the causes of the increasing number of internet addiction cases and will be a serious problem in the future (Andreassen et al., 2012; Teke, 2011).

This phenomenon becomes a thing that needs to be curbed as a result of the high percentage of individuals engaging in internet use will end up with excessive use (addiction) and engaging in unhealthy activities (Ghina \& Griffiths, 2006). According to Donald (1994), excessive and extreme use of cyber leads to various problems including causing individuals to like to sit alone, reducing face-to-face interaction so that they are not sensitive to certain feelings and reactions around them (Donald, 1994). A study by Rice (2005) found that cyber or internet addiction is a compulsive tendency that will interfere with an individual's ability to lead a normal life (Rice, 2005).

Cyber addiction also sometimes causes extreme emotional stress among its users as well as decreases the function of daily activities (Shapira et al., 2002). Therefore, this addiction should not be taken lightly and should be curbed immediately. 
Among the negative effects on the social development of adolescents are weaknesses in language proficiency, social skills that are incapable of understanding body language (Al Mazmi, Aslam \& Rajan, 2013). The existence of this matter was observed during this study and among the reasons is the existence of application content, advertisements and information in inappropriate technology, such as pornographic and extreme scenes that affect the behavior and thinking of adolescents.

In a field study of student behavior that has been made by Tessa (2014), found that as many as 64 percent of students on campus interact with their devices and this seems to indicate they are addicted to the cell phones they own. However, this study also found that students have an awareness that negative psychological effects exist on users if excessive use of mobile phones is done. In addition, the use of mobile phones also affects peers and the impact in developing relationships such as family.

A study conducted by Garrison, Liekweg and Christakis (2011), found that the decline in subject grades has occurred due to too long use of gadgets and video games among students. In addition, this study also found a reduction in human relationships, especially with parents themselves. According to Anderson and Bushman (2016) the content contained in the gadget media allows teenagers to freely access it and this easily encourages teenagers to acquire negative materials. The effects on adolescents' attitudes, behaviors and cognitive will occur and are prone to violence when video games can be played in gadgets.

\section{Literature Related to Cyber Addiction in Malaysia}

Internet usage in Malaysia has increased dramatically lately with 89.3 percent of the Malaysian population considered internet users in 2017 compared to 80 percent in 2016 (SKMM, 2017). According to Youb (2010), about 60,000 students aged between 12 to 18 years in Malaysia spend at least four hours a day surfing the internet, especially on social media. The rotation period of between three to five hours of internet use in a day is considered to have symptoms of addiction. This is supported by a study from Norton Online Living Report (NOLR) on internet use habits found that Malaysian teenagers spend up to 16 hours a week surfing the internet (Hasan \& Shahrina, 2012).

According to Das, Bullare and Ibrahim (2014), internet use among adolescents in Malaysia is high with the findings of their study found that normal users are high at 59\%, risk group at $34 \%$ ) and critical level at $6.8 \%$. This study is supported by other studies including studies by Hassan and Shahrina (2012) and Rafidah (2010). All these studies found a sharp increase in cyber addiction among the community in Malaysia, especially among adolescents. In fact, they predict that if this situation continues and is not controlled properly, the increase in internet addiction among adolescents will have a negative impact on the larger ones, especially on adolescents.

This internet addiction will usually lead to negative effects on other aspects as well. Internet fraud, pornographic website browsing and privacy intrusion are the main effects of internet addiction in Malaysia (Pitchan, 2017). Study by Azis (2008) and Anuar (2003) state that almost $25 \%$ of pornographic websites are accessed by Malaysians. Cyber sex addiction covers a wide spectrum including the use of compulsive (compulsive) use of pornographic / pornographic 
websites and online sex. This cybersex addiction has a very significant negative impact on the users themselves and those around them (Zakaria \& Baharuddin, 2011; Young, 2000).

The development of information technology takes time to provide many facilities and benefits in human life. Lifestyle has also changed due to the development of this technology, even creating a new form of culture to society today. The nature of being too obsessed with the use of technology has to some extent changed one's lifestyle. According to Ismail (2019) statistics released by the National Information Technology Council (NITC) show that users who use the internet in 2018 in Malaysia have reached 16.9 million people. According to Shahrizan (2019), the most widely used social site to reach 10.2 million people is "Facebook". In fact, Malaysia is one of the highest using facebook in the world today.

Once upon a time, there was an era of change, namely 'Maid replaces Parents' in the process of raising children in Malaysia. However, this phenomenon has changed since the advent of gadgets in today's society. This phenomenon is contagious to the community outside of Malaysia. According to Sharon (2014), some parents feel that the use of Ipad can help and facilitate in carrying out work at home, in fact this technology is able to control the movement of children if in someone else's house or anywhere. However, it can cause various other problems without being noticed by parents, especially in the brain shrinking of children when overused in the use of gadgets by children less than three years old. According to Fatin Arifa (2017), this gadget addiction does not only look at physical electronic devices, but also involves all forms of material through the gadget.

\section{Conclusion}

The use of gadgets is one thing that has a huge impact. It facilitates in various forms of human life. However, overuse of these gadgets can sometimes lead to other problems such as addiction and health problems. In Malaysia, various factors have been the cause of this gadget addiction problem. An effort to overcome this addiction needs to be made so as not to lead to bigger problems.

\section{Acknowledgement}

This article is a part of research under Fundamental Research Grant Scheme (FRGS), FRGS/1/2019/SSI03/UNISZA/02/2, and is supported by the Ministry of Education and Universiti Sultan Zainal Abidin (UniSZA).

\section{References}

Anas, W. N. I. W. N., Khairuldin, W. M. K. F. W. K., Mohd, H., \& Ali, A. K. (2020). Rehabilitation of Transsexual Based on Preaching Psychology in Islam. International Journal of Disaster Recovery and Business Continuity. Vol. 11 (1), pp. 682-687

Anas, W. N. I. W. N., Khairuldin, W. M. K. F. W., Embong, A. H., Mohd, H., \& Mokhtar, W. K. A. (2020). Trend of transsexualism problem and its implications towards muslim community in malaysia. International Journal of Pharmaceutical Research, 12(4), 25-29

Omar, S., \& Latip, M. (2015). Pengaruh Peranti Teknologi Kepada Perkembangan Sosial Dan Permasalahan Kesihatan Kanak-Kanak

Jabar, B. H. A. (2019). Taasub Gajet Makin Menghakis Nilai Murni, https://www.bharian.com.my/kolumnis/2019/12/641833/taasub-gajet-makinmenghakis-nilai-murni . Accessed on 10th January 2021. 
Forouzan, B. A., \& Fegan, S. C. (2003). Data Communication and Networking. Edisi ke-4. New York: McGraw-Hill

Fazree, S. D., \& Zakaria, S. M. (2018). Kesan Penggunaan Gajet kepada Perkembangan Kognitif dan Sosial Kanak-Kanak Prasekolah, Jurnal Wacana Sarjana, 2(4), 1 - 6.

Manumpil, B., Ismanto, Y. \& Onibala, F. (2015). Hubungan Penggunaan Gadget Dengan Tingkat Prestasi Siswa Di Sma Negeri 9 Manado, ejoural Keperawatan (e- Kep), 3(2).

Parzi, M. N. (2019). Pengaruh Gajet terhdap Kanak-Kanak Membimbangkan. https://www.bharian.com.my/berita/nasional/2019/11/632517/pengaruh-gajetterhadap-kanak-kanak-membimbangkan Accessed on 14th of January 2021.

Sadri, A. (2018). Prolonged digital screen effect on preschool children: An analysis from the perception of parents of Dhaka [Unpublished Master of Developmental Studies Thesis]. BRAC University.

Raslan, A. M., \& Aini, Z. (2018). Pencapaian Internet dalam Kalangan Remaja Islam,AtTahkim,Jil.8,No.5. pp. 80-91

Ismail, A., Mansor, S. N. (2020), Kesan Permainan Video terhadap Perkembangan KanakKanak, BITARA International Journal of Civilizational Studies and Human Sciences,Jil.3, No.1.

Hashim, N., \& Razaliz, A. (2019).Teknologi dan Media Sosial dalam Komunikasi Ibu Bapa dan Anak-Anak, Malaysian Journal of Communication,Jil.35,no.4.

Barnadib. (1982). Arti dan Metode Sejarah Pendidikan.Yogyakarta:Yayasan Penerbitan FIPIKIP.

Krippendorff, K. (2004). Content Analysis:An Introduction to Its Methodology( $2^{\text {nd }}$ ed).Thousand Oaks,CA:Sage.

Yusof, R. (2004). Penyelidikan Sains Sosial,Selangor: PTS Publication dan Distributors. 